\title{
Cost Control Application Research of Value Engineering in the Design Phase of Construction Project
}

\author{
Li Ning \\ Beijing Institute of Economic \& Management, Beijing,China \\ 1234@163.com
}

Key words: value engineering, construction project, cost control.

\begin{abstract}
At abroad, the construction industry is the main area applying value engineering. In China, apart from industry business, the construction industry is the most important area involving the application of value engineering. But a study made by Guangdong construction industry shows that many enterprise managers don't have a clue about the value engineering. At present, the value engineering in construction industry is still at quite a low level. The popularization and application of value engineering in construction industry will make it easier for the construction industry eradicate the problems of long construction period, large waste, poor quality and high cost. Value engineering can make up for the shortcomings of these methods, for it studies allocation of product's properties and its cost based on its functions, and it emphasizes the organic combination of the improvements of products' function and the reduction of the cost. As long as the value engineering is practically popularized, the appearance of construction industry is bound to change.
\end{abstract}

\section{Introduction}

Value engineering, a subject about technology and economy dedicated to improve the function of product or system, and reduce the cost of product or system, therefore with the lowest life cycle cost to meet customers' requirements about function. The application of value engineering focuses on the design phase of the research of development of the product, which is an important characteristic of value engineering. Compared with other countries, there is certain disparity in both the theoretical research and practical application of value engineering in the construction industry in our country. Therefore we have to catch up. So using value engineering methods to control cost in the most productive phase of value engineering - design phase bears great practical significance.

\section{Characteristics of Value Engineering Application in the Design Phase of Construction Project}

As a kind of productive and creative activity, value engineering is not only used in machinery manufacturing industry to guide the design, but also is needed in basic construction and the construction industry to guide the design. Although there are many similarities of the application of value engineering used respectively in construction design and the industrial products' design, due to the fact that the production activities and product of basic construction and the construction industry bear their own characteristics, so on the one hand, it increases the difficulty of the engineering application of value engineering, on the other hand, it forms the characteristics of engineering application of value engineering which are different from industrial product design.

(1)Application of value engineering in engineering design is different that of product design.

In general, the research object of value engineering in the product design is the product, the function refers to the product's function that the user requires, the cost refers to the production cost and use-cost, and its aim is to reliably meet the user's request with the lowest life cycle cost. And in engineering design, the research object is a portion of the project or structure, such as factories, buildings or a certain component etc. Function refers to the operating function of the country or the users about the project. In general, in addition to the function, quality of the project, there are time requirements about project delivery. Cost refers to the construction cost and maintenance cost after use in the entire project or some part of the project. The purpose of value engineering application is 
to develop a low cost, high function scheme with the lowest cost to realize of nation or users' requirements of the project.

(2)When value engineering application used in engineering design, its designed cost goal is different from the value engineering application used in product design.

The prices of industrial products are generally stipulated by the state. Based on the given price to deduct tax, profits and some circulation cost, we can calculate out the social cost of a certain kind of product. Application of value engineering in product design can based on the above information and the enterprise's specific circumstances to apply the appropriate methods to set cost targets, so as to guide and control product program.

Yet, due to the fact that the construction products bears oneness characteristic, the production is not fixed in a certain place and there is long production process and numerous links, which make the building products must pass a special design program, namely, determine the price by using the separate programming budget in basic construction. Specifically speaking, it is based on the construction drawings and budget quota to calculate the quantity of divisions and departments; Select a set of budget unit price, then calculate direct fee; then based on the direct fee or artificial cost to calculate the indirect fee; and then according to the feeing standard to calculate independent cost and planned profit; finally, calculate the unit project budget cost in general. Clearly, this method of defining price is different from general industrial product pricing method. The determination of the cost target while applying value engineering in the engineering design can be only based on the engineering budget and according to the specific circumstances with appropriate method to achieve a reasonable result.

\section{The General Procedure of Value Engineering Work}

The process of value engineering is a process of discovering analyzing and solving problems. Value engineering work procedures are shown in table 1.

Table 1 the general procedure of value engineering work

\begin{tabular}{|c|c|c|c|}
\hline $\begin{array}{l}\text { General } \\
\text { process }\end{array}$ & Basic steps & Detailed steps & Problems to be tackled \\
\hline \multirow{4}{*}{ analysis } & \multirow{2}{*}{$\begin{array}{l}\text { The process of } \\
\text { define and sort out } \\
\text { the function }\end{array}$} & $\begin{array}{l}\text { 1. choose an object } \\
\text { 2.gather and sort out materials }\end{array}$ & $\begin{array}{l}\text { (1)what the research object of value } \\
\text { engineering? }\end{array}$ \\
\hline & & $\begin{array}{l}\text { 3.define the function } \\
\text { 4.sort out the function }\end{array}$ & (2)The function? \\
\hline & \multirow[b]{2}{*}{$\begin{array}{l}\text { Evaluation of the } \\
\text { function }\end{array}$} & 5.analyze the cost of function & (3)The cost? \\
\hline & & $\begin{array}{l}\text { 6.evaluation of the function } \\
\text { 7.determine the scope of object }\end{array}$ & (4)The value? \\
\hline generalize & \multirow[b]{2}{*}{$\begin{array}{l}\text { Stipulate } \\
\text { improvement } \\
\text { solution }\end{array}$} & 8.create a scheme & $\begin{array}{l}\text { (5)Are there any other methods to } \\
\text { achieve the same function? }\end{array}$ \\
\hline evaluation & & $\begin{array}{l}\text { 9.examine and approve } \\
\text { 10.implement and inspect } \\
\text { 11.identify the results } \\
\text { 12.make proposals }\end{array}$ & $\begin{array}{l}\text { (6)The cost of new plan? } \\
\text { (7)Does the new plan meet the } \\
\text { requirements? }\end{array}$ \\
\hline
\end{tabular}

From table 1 we can know that: the working process of the value engineering is in essence aims at the research object of value engineering to carry out seven basic issues, and the seven issues determines the basic steps and working process of value engineering.

4. Cost Control of Construction Project

The cost control of construction project mainly lies in the investment decision-making stage, design stage and the implementation stage during construction. It aims to control the project investment within the approved cost quota and correct the deviation at any time, thus to ensure the implementation of project investment management objectives can be achieved, finally, to achieve maximum investment benefit by rational use of manpower, material resources and financial resources.

Investment control mainly includes the following five aspects: first, in the feasibility study stage, the cost control can accurately estimate investment, thus guarantee the control of total investment 
estimation. Second, keep the investment within the limit of the construction unit quota, which means to control the preliminary design within the investment budget, design budget, and the contracting contract price and the later contract price adjustment control within the design budget. Third, put the construction project investment cost among each project, each unit project and each component project, and allocate investment project cost among each investment project. Fourth, make the investment of construction unit gain as more as possible, therefore, the investment management should not only consider the cost, but also consider the functional requirement of the engineering and construction period, thus to combine the above three aspects well. Fifth, not only the investment should be taken into consideration, but also the recurring expense of construction project should be taken into consideration, namely the total cost should also be taken into consideration.

From the perspective of cybernetics, the cost control in the design phase means to analyze various factors appear in the designing process and the affecting degree of these factors to the engineering cost, then take effective preventing measures to avoid or reduce the influence of various factors on the engineering cost. Therefore, the cost control in the design phase prior to the construction of the project is positive and active control. The later part of this paper will presents various factors affecting the engineering cost at the design stage and all kinds of measures involved in the design stage of engineering cost control.

\section{Using Value Engineering to Analyze the Construction Cost Cases}

For the same construction project, the same item, even the same engineering unit, due to the fact that their design schemes are different, thus their costs would invariably be different. And value engineering emphasizes "good" meaning to improve the function, while "cheap" is to reduce the cost ratio. Therefore, choosing with the value engineering scheme is in essence to pick out a design scheme that is qualified, reliable, with low cost in whole life cycle and can well realize the function of the engineering.

Project background: there is a unit's residential building project with poor proposed address conditions, and its upper cover is only about one meter thick, besides, the deposition of dirt is as deep as ten meters. In the whole designing process, the application of value engineering principle is used to carry out activities. While the residential use function is satisfied, we should try to reduce the project cost. The concrete implementation steps are as follows:

1. Select the research object of value engineering. Make the residential building as the research object of value engineering project

2. Data collection. The data should be collected in the following aspects:

(1) Visit the construction spot to collect user's expectations or advice towards the residential building.

(2) Survey some of the region's residential construction costs.

(3) Visit the construction units to learn about some information of residential construction.

(4) Collect a large amount of new technology and new material about housing construction and other data.

(5) According to different foundation forms, storey heights and decorate residential construction to analyze various technical and economic indicators of residential buildings in recent years.

3. The process of defining and sorting out the function. Architectural function refers to the sum of properties of the products meeting the needs of the society. Different construction products have different functions, which can be reflected through a series of construction factors reflecting the application requirement of the building. Here we put the residential building as a complete and independent "product" to be defined and sorted out. Value engineering team is formed by relevant personnel from design, construction and the construction unit. After mutual discussion and analysis of the function of the residential buildings, the functions can be generalized into four aspects: application function, security function, aesthetic function and other functions. 


\section{Evaluation of the function}

The process of sorting out the function generalize the function of the residential building into four types including twelve kinds, these twelve kinds of functions have different degrees of importance in the residential function, therefore, each coefficient of function evaluation needs to be calculated out as the importance weight of the function. In the residential unit's project, we use weighted scoring method against the users, designers and construction unit. The weight figure of the above three factors are respectively $55 \%, 30 \%$ and $15 \%$. The functional importance coefficients are shown in table 2.

Among which:

Functional importance coefficient $\phi_{i}=\frac{0.55 F_{i 1}+0.3 F_{i 2}+0.15 F_{i 3}}{100}$

Table 2 the point table of function importance coefficients

\begin{tabular}{|c|c|c|c|c|c|c|c|c|}
\hline \multicolumn{2}{|c|}{ functions } & \multicolumn{2}{|c|}{ User ratings } & \multicolumn{2}{|c|}{$\begin{array}{l}\text { Designers } \\
\text { ratings }\end{array}$} & \multicolumn{2}{|c|}{$\begin{array}{c}\text { Construction } \\
\text { organization ratings }\end{array}$} & \multirow{2}{*}{$\begin{array}{c}\text { Functional } \\
\text { importance } \\
\text { coefficient } \varphi_{i}\end{array}$} \\
\hline & & $\mathrm{F}_{\mathrm{i} 1}$ & $0.55 \mathrm{~F}_{\mathrm{i} 1}$ & $\mathrm{~F}_{\mathrm{i} 2}$ & $0.3 \mathrm{~F}_{\mathrm{i} 2}$ & $\mathrm{~F}_{\mathrm{i} 3}$ & $0.15 \mathrm{~F}_{\mathrm{i} 3}$ & \\
\hline \multirow{3}{*}{$\begin{array}{l}\text { Suitability } \\
\qquad \mathrm{F}_{1}\end{array}$} & Plane layout $\mathrm{F}_{11}$ & 39 & 21.45 & 30 & 9.00 & 35 & 5.25 & 0.3570 \\
\hline & $\begin{array}{l}\text { Height and storeys } \\
\mathrm{F}_{12}\end{array}$ & 2 & 1.10 & 4 & 1.20 & 4 & 0.60 & 0.0290 \\
\hline & $\begin{array}{l}\text { Lighting and } \\
\text { ventilation } F_{13}\end{array}$ & 17 & 9.35 & 14 & 4.20 & 15 & 2.25 & 0.1580 \\
\hline \multirow{2}{*}{$\begin{array}{l}\text { Security } \\
\mathrm{F}_{2}\end{array}$} & Durability $F_{21}$ & 21 & 11.55 & 15 & 4.50 & 20 & 3.00 & 0.1905 \\
\hline & $\begin{array}{c}\text { Three prevention } \\
\text { facilities } \mathrm{F}_{22}\end{array}$ & 4 & 2.20 & 5 & 1.50 & 3 & 0.45 & 0.0415 \\
\hline \multirow{3}{*}{ Artistic $F_{3}$} & $\begin{array}{l}\text { Architectural } \\
\text { image } \mathrm{F}_{31}\end{array}$ & 2 & 1.10 & 10 & 3.00 & 2 & 0.30 & 0.0440 \\
\hline & $\begin{array}{c}\text { The interior and } \\
\text { exterior } \\
\text { decorationF } F_{32}\end{array}$ & 6 & 3.30 & 8 & 2.40 & 6 & 0.90 & 0.0660 \\
\hline & $\begin{array}{c}\text { The interior } \\
\text { decoration } \mathrm{F}_{33}\end{array}$ & 2 & 1.10 & 2 & 0.60 & 1 & 0.15 & 0.0185 \\
\hline \multirow{4}{*}{ Others $\mathrm{F}_{4}$} & $\begin{array}{c}\text { Environmental } \\
\text { design } \mathrm{F}_{41}\end{array}$ & 1.5 & 0.83 & 5 & 1.50 & 6 & 0.90 & 0.0323 \\
\hline & $\begin{array}{c}\text { Technical } \\
\text { parameters } \mathrm{F}_{42} \\
\end{array}$ & 4 & 2.20 & 2 & 0.60 & 2 & 0.30 & 0.0310 \\
\hline & $\begin{array}{c}\text { Ease of } \\
\text { construction } \mathrm{F}_{43} \\
\end{array}$ & 1 & 0.55 & 3 & 0.90 & 5 & 0.75 & 0.0220 \\
\hline & $\begin{array}{c}\text { Convenient design } \\
\mathrm{F}_{44} \\
\end{array}$ & 0.5 & 0.28 & 2 & 0.60 & 1 & 0.15 & 0.0103 \\
\hline \multicolumn{2}{|c|}{ Total number } & 100 & 55 & 100 & 30 & 100 & 15 & 1 \\
\hline
\end{tabular}

The table shows that for the design of this building, the most important function is plane layout: followed by durability; and last is the lighting and ventilation.

5. The design and evaluation of the scheme

Based on the collected data and the results generalized from the above function importance coefficients, the designers created a dozen different solutions by brainstorming. After value engineering personnel have conducted the qualitative analysis by enumeration of the advantages and disadvantages of these schemes, they reserved the following authoritative five quantitative schemes to be evaluated, thus to further select the better ones, as shown in table 3 . 
Table 3 calculation table of residential project cost coefficient

\begin{tabular}{c|l|c}
\hline $\begin{array}{c}\text { Schemes' } \\
\text { names }\end{array}$ & \multicolumn{1}{c}{ Major features } & $\begin{array}{c}\text { The cost of per } \\
\text { square meter } \\
\left(\text { yuan } / \mathrm{m}^{2}\right)\end{array}$ \\
\hline A & $\begin{array}{l}\text { The 6-layers' structure, height of each storey: 3m, the outer wall with 370mm brick, the } \\
\text { inner wall with 240mm brick, pile foundation beam is prefabricated, each storey is } \\
\text { designed with beams in each storey. The outer decoration is plain, the interior } \\
\text { decoration is good with good sanitary equipments. }\end{array}$ & 1085 \\
\hline B & $\begin{array}{l}\text { The 6-layers' structure, height of each storey: 2.9m, the inner and outer walls are of } \\
\text { 240mm and 120mm thick respectively. The walls are no bearing walls, reinforced } \\
\text { concrete strip foundation with beams in each storey. Both the outer and the inner } \\
\text { decorations are average. }\end{array}$ & 824 \\
\hline C & $\begin{array}{l}\text { The 6-layers' structure, height of each storey: 3m, both the outer and the inner wall with } \\
\text { 240mm brick. Pile foundation with beams in each storey and structural columns. The } \\
\text { outer decoration is plain, the interior decoration and other facilities are good. }\end{array}$ & 1024 \\
\hline D & $\begin{array}{l}\text { The 6-layers' structure, height of each storey: 3m, both the outer and the inner wall are } \\
\text { made of hollow brick of 240mm. Reinforced concrete raft foundation with beams in each } \\
\text { storey. The decoration and facilities are average. }\end{array}$ & 875 \\
\hline & $\begin{array}{l}\text { The 6-layers' structure, height of each storey: } 2.9 \mathrm{~m}, \text { both the outer and the inner wall are } \\
\text { with 240mm thick brick. Pile foundation with beams in each storey and structural } \\
\text { columns. The decoration and facilities are average. }\end{array}$ & 864 \\
\hline & \multicolumn{1}{c}{ Total number } & 4632 \\
\hline
\end{tabular}

In order to choose the optimal scheme among the five reserved schemes, the value engineering staff decide to adopt the geometric average method and to combine both in the aspects of technology and economy to comprehensively determine the most reasonable solution. Therefore, a value engineering personnel evaluate comprehensively with the following steps:

(1) Calculate the technical index and economic index of each scheme. The technical rating of each alternative and the concrete calculation results of technical index are shown in table 3.

Because that there are only one evaluation index - unilateral cost among the economic indicators of this project, we can rely on the following equation to directly calculate out the economic index:

$$
E I_{i}=\frac{C^{n}-C_{i}}{\sum_{i=1}^{m}\left(C^{n}-C_{i}\right)} \quad i=(1,2, \cdots, m)
$$

In the above equation, $E I_{i}$ represents economic factor;

$C^{n}$ represents the biggest limit of each scheme of unilateral cost.

$C_{i}$ represents the unit cost of the ith scheme. 
Table 4 The calculation table of function's satisfaction degree and its coefficient

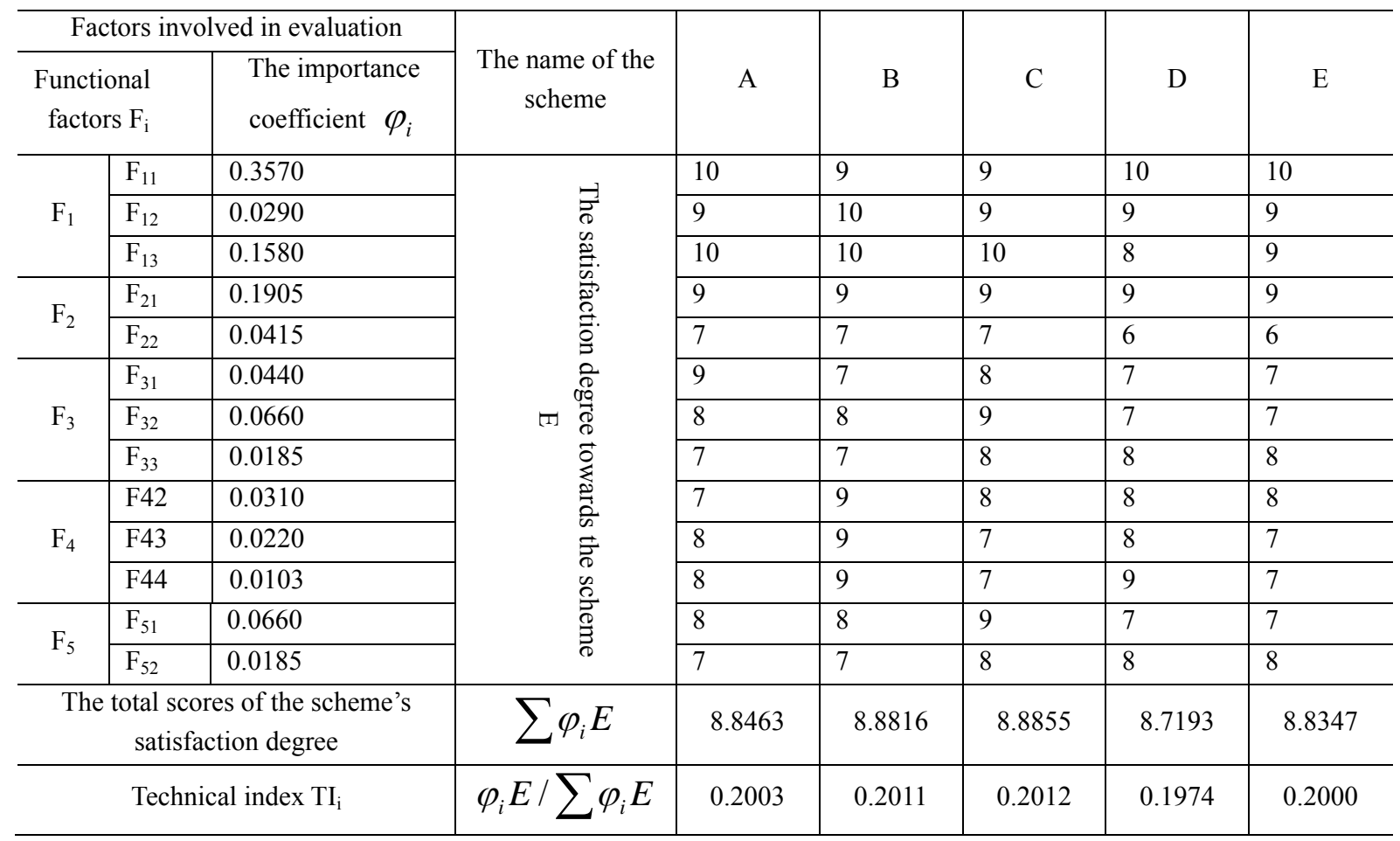

Unilateral cost maximum $\operatorname{limit} C^{\prime \prime}=1300$, and the economic indexes of each scheme are respectively:

$$
E I_{A}=0.1176, E I_{B}=0.2604, E I_{C}=0.1510, E I_{D}=0.2325, E I_{E}=0.2385
$$

(2) Based on the formula $K_{i}=\sqrt{T I_{i} \times E I_{i}}$ to calculate the geometric average of these schemes, and the specific calculation results are as shown in table 5.

Table 5 The table of geometric average schemes

\begin{tabular}{c|c|c|c|c|c}
\hline Schemes' names & $\mathrm{A}$ & $\mathrm{B}$ & $\mathrm{C}$ & $\mathrm{D}$ & $\mathrm{E}$ \\
\hline $\mathrm{TI}$ & 0.2003 & 0.2011 & 0.0212 & 0.1974 & 0.2000 \\
\hline $\mathrm{EI}$ & 0.1176 & 0.2604 & 0.1510 & 0.2325 & 0.2385 \\
\hline $\mathrm{K}$ & 0.1535 & 0.2288 & 0.1743 & 0.2142 & 0.2184 \\
\hline
\end{tabular}

Listing the calculated results in table 5, we can find that plan B has the highest geometric average among the five plans. Thus, we take this plan as the optimal one in the aspects of indexes of economy and the optimal technical indicators. In few years of study carried by the author about this area towards similar residential building projects, we can find that the average cost is 1800 yuan per square meter in this area. Meanwhile the plan B only costs 1500 yuan saving $16.7 \%$ of the construction cost, which indicates that the value engineering plays a big role.

\section{Conclusion}

Value engineering is a kind of quantitative method creating project value, and it is the embodiment of the maximum value of the whole system or product through the perfect matching of value and function. Currently, research direction of value engineering mainly focuses on the selection of the models of product design and construction projects, while the models of design scheme in the construction projects are fewer. At present, construction design requires to meet the functional requirements of the users and to achieve the most reasonable cost function, while according the traditional method basing on the experience to is not in conformity with the current economic situation and the real estate environment. How to use scientific methods to guide the 
project design is the demand of developing the real estate, which is also the need of the developing multidisciplinary value engineering. This paper, based on this perspective, applies value engineering to the project design to meet the requirements of continuously put forward the development of the real estate design and makes the value engineering meet the requirements of developing value engineering theory at the same time.

\section{References}

[1] Zhang Wenku, Liu Min, Fang Xiumu, Cai Benqiang. The First Try for the Energy Saving of Buildings with Shopping Malls-Building Energy saving Design of Shopping Plaza in Harbin Lesong Community[J]. Construction Technology, 2003,08:24-25.

[2] Fugang, Long Enshen. The Study of the Influence of External Thermal Insulation on the Mall's Energy Consumption[J]. Refrigeration and Air Conditioning,2010,04:101-104.

[3] Lv Jian, Guo Shiwei, Jiang Ying, Zhang Junmei. Energy Consumption Status and Energy Saving Analysis of Typical Buildings with Shopping Malls in Tianjin City[J]. Construction Technology, 2008,06:29-3 